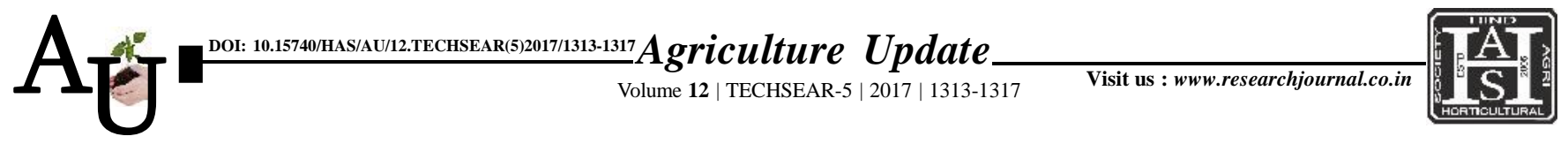

\title{
Research Article: Different technologies adopted by awardee farmers in Konkan region of Maharashtra
}

\author{
N.D. KALE, A.N. DESAI AND S.M. GHOLAPE
}

Article Chronicle:

Received :

15.07.2017;

Accepted :

30.07.2017

KEY WoRDS:

Awardee farmers, Technologies adopted

SUMMARY : Present research work was aimed at throwing light on the successful farmers who got the recognition from government for their achievement in farming. Present study was conducted in Ratnagiri, Raigad, Sindhudurg, Thane and Palghar districts of Konkan region. The sample was constituted 60 'State agricultural award' received farmers drawn from different villages of Konkan region. The ex-postfacto research design was used for the present study. The analysis of data revealed that, majority $(73.33 \%)$ of the respondents was 'middle' age, 40.00 per cent had 'higher secondary' education, 'medium' (73.33\%) farming experience, 'medium' (40.00\%) size of land holding, 'medium' (46.67\%) annual income and undergone 'medium duration'(56.66 \%) training. All the respondents received awards from 'state level' and majority of them received from 'private organizations, NGOs'. Majority (70.00\%) of the respondents had 'medium' information seeking behaviour, 'high' (61.67\%) management orientation and had 'medium' $(85.00 \%)$ productivity level. It is observed that, the awardee farmers are practicing contour farming $(83.34 \%)$, they also did crop planning according to agro-climatic conditions $(86.68 \%)$, and after that crop cultivation according to agro- climatic conditions $(86.68 \%)$. Whereas, use of improved and hybrid verities $(90.00 \%)$, some of the awardee farmers are also adopting organic farming (33.34\%), soil testing (93.34\%), INM practice (75.00\%), IPM practice (80.00\%), use of green manuring crops $(73.34 \%)$. The awardee farmers highly adopting new things like use improved agricultural implements and equipment's (100.00\%), use of micro-irrigation (86.67\%), use of non- conventional energy resources $(60.00 \%)$, use of vermicompost $(41.67 \%)$.

How to cite this article : Kale, N.D., Desai, A.N. and Gholape, S.M. (2017). Different technologies adopted by awardee farmers in Konkan region of Maharashtra. Agric. Update, 12(TECHSEAR-5) : 1313-1317; DOI: 10.15740/ HAS/AU/12.TECHSEAR(5)2017/1313-1317.

Author for correspondence :

\section{N.D. KALE}

Department of

Extension Education,

Vasantrao Naik

Marathwada Krishi

Vidyapeeth, PARBHANI

(M.S.) INDIA

Email : kaleneha26@

gmail.com

See end of the article for

authors' affiliations 